\title{
APLIKASI MODIFIED CASSAVA FLOUR (MOCAF) SEBAGAI BAHAN PENGISI PADA SOSIS AYAM
}

\author{
ARYA MAHDI \\ RAMIDZI HASBHI HOSNAINI
}

Fakultas MIPA

Universitas PGRI Banyuwangi

email: aryamahdi0771@gmail.com

\begin{abstract}
ABSTRAK
Salah satu alternatif bahan pengisi dalam pembuatan sosis ayam adalah MOCAF (Modified Cassava Flour) yang memiliki karakter yang berbeda dengan tepung tapioka, terutama dalam hal derajat viskositas, kemampuan gelasi, daya rehidrasi, WHC (Water Holding Capacity), dan kemudahan melarut yang lebih baik. Penelitian ini bertujuan untuk mengetahui sifat fisik, kimia, dan organoleptik sosis ayam dengan penambahan MOCAF serta mengetahui persentase penggunaan MOCAF untuk menghasilkan sosis ayam dengan sifat fisik, kimia, dan organoleptik yang baik dan disukai. Penelitian dilaksanakan di Laboratorium Biokimia Jurusan Biologi Fakultas MIPA Universitas PGRI Banyuwangi. Penelitian dilakukan pada bulan oktober 2015 sampai bulan januari 2016. Perlakuan yang diberikan yaitu penggunaan 100\% MOCAF (A1), 75\% MOCAF dan 25\% Tapioka (A2), 50\% MOCAF dan 50\% Tapioka (A3), $25 \%$ MOCAF dan $75 \%$ Tapioka (A4), serta 100\% Tapioka (A5). Data hasil uji karakteristik fisik dan kimia dianalisis menggunakan rancangan acak lengkap. Kemudian data uji sensoris dianalisis menggunakan uji hedonik. Hasil penelitian menunjukkan bahwa penggunaan MOCAF sebagai bahan pengisi pada sosis ayam dapat mempengaruhi kadar air, kadar protein, dan kadar karbohidrat sosis ayam yang dihasilkan. Semakin banyak penambahan MOCAF dapat meningkatkan kadar air, kadar protein, serta menurunkan kadar karbohidrat sosis ayam yang dihasilkan. Berdasarkan uji kesukaan keseluruhan diperoleh perlakuan dengan penggunaan MOCAF 25\% dan Tapioka 75\% (A4) adalah sampel yang paling disukai dengan kadar kadar air sebesar 60,49\%, kadar protein 14,62\%, kadar lemak 1,10\%, kadar abu 2,42\%, dan kadar karbohidrat $21,37 \%$.
\end{abstract}

Kata kunci: MOCAF (Modified Cassava Flour), Sosis ayam, Tapioka, Organoleptik

\section{PENDAHULUAN}

Pendidikan Jasmani, Sebagai upaya diversifikasi pangan dapat dilakukan substitusi komoditi pangan lokal (indigenous resources) pada pembuatan sosis. Upaya ini dilakukan untuk memanfaatkan sumber karbohidrat lain secara optimal yang merupakan bahan pangan lokal. MOCAF (Modified Cassava Flour) mempunyai potensi untuk digunakan sebagai bahan pengisi pada pembuatan sosis ayam [1]. Permasalahan yang timbul adalah belum diketahuinya persentase penggunaan MOCAF yang tepat 
untuk menghasilkan sosis ayam dengan karakteristik yang baik dan disukai. Tujuan Penelitian ini untuk mengetahui sifat fisik, kimia, dan organoleptik sosis dengan penambahan MOCAF sebagai bahan pengisi pada pembuatan sosis ayam[2].

\section{METODE}

Metode Penelitian ini dilakukan dengan menentukan formulasi bahan dan dilakukan pengulangan pengamatan sebanyak tiga kali. Perlakuan pada pembuatan sosis dilakukan dengan variasi : Penggunaan $100 \%$ MOCAF, Penggunaan $75 \%$ MOCAF $+25 \%$ tapioca, Penggunaan $50 \% \mathrm{MOCAF}+50 \%$ tapioca, Penggunaan $25 \%$ MOCAF $+75 \%$ tapioca, Penggunaan $100 \%$ tapioca. Data hasil uji karakteristik fisik dan kimia dianalisis menggunakan Analisis of Varian (ANOVA) rancangan acak lengkap pola searah. Perbedaan rata-rata diuji dengan uji Duncan's new multiple range test pada taraf uji $\alpha$ $\leq 5 \%$. Data uji sensoris dianalisis menggunakan uji Hedonik [3].

\section{HASIL DAN PEMBAHASAN}

Parameter dalam penelitian ini adalah :

A. Sifat fisik Sosis Ayam yang meliputi warna dan tekstur. Warna yang diamati dalam penelitian ini adalah derajat putih (Whiteness) sosis ayam matang. Nilai whiteness sosis ayam yang dihasilkan berkisar antara 40,83 41,37 seperti pada Tabel 1 berikut ini :
Tabel 1 Sidik Ragam Warna Sosis

Ayam

\begin{tabular}{lcclcc}
\hline $\begin{array}{c}\text { Sumber } \\
\text { Keragaman }\end{array}$ & db & $\begin{array}{c}\text { Jumlah } \\
\text { Kuadrat }\end{array}$ & $\begin{array}{c}\text { Kuadrat } \\
\text { Tengah }\end{array}$ & $\begin{array}{c}\text { F } \\
\text { Hitung }\end{array}$ & $\begin{array}{c}\mathbf{F} \\
\text { Tabel } \\
\mathbf{5 \%} \\
\mathbf{1 \%}\end{array}$ \\
\hline Perlakuan & 4 & 0,5626 & 0,1406 & $\begin{array}{l}192,320 \\
4 * *\end{array}$ & 3,48 \\
& & & & & 5,99 \\
Galat & 10 & 0,0073 & 0,0007 & & \\
Total & 14 & 0,5699 & & & \\
\hline
\end{tabular}

Keterangan: ** Berbeda sangat nyata $\mathrm{CV}=0,7 \%$

Pengukuran tekstur dilakukan terhadap sosis ayam matang. Nilai tekstur yang dihasilkan berkisar antara 26,76 29,23 . Semakin tinggi nilai tekstur, maka tekstur sosis ayam yang dihasilkan semakin keras. Sidik ragam nilai tekstur sosis ayam disajikan pada Tabel 2, menunjukkan bahwa penambahan MOCAF dapat berpengaruh sangat nyata terhadap tekstur sosis ayam yang dihasilkan. Semakin banyak penambahan MOCAF, maka tekstur sosis ayam yang dihasilkan semakin lunak.

Tabel 2 Sidik Ragam Tekstur Sosis Ayam

\begin{tabular}{|c|c|c|c|c|c|}
\hline $\begin{array}{c}\text { Sumber } \\
\text { Keragaman }\end{array}$ & $\mathbf{d b}$ & $\begin{array}{c}\text { Jumlah } \\
\text { Kuadrat }\end{array}$ & $\begin{array}{c}\text { Kuadrat } \\
\text { Tengah }\end{array}$ & $\begin{array}{c}\text { F } \\
\text { Hitung }\end{array}$ & $\begin{array}{c}\mathbf{F} \\
\text { Tabel } \\
5 \% \\
1 \%\end{array}$ \\
\hline Perlakuan & 4 & 11,0562 & 2,7641 & $\begin{array}{l}7,1599 * \\
*\end{array}$ & $\begin{array}{l}3,48 \\
5,99\end{array}$ \\
\hline Galat & 10 & 3,8605 & 0,3860 & & \\
\hline Total & 14 & 0,5699 & 14,9167 & & \\
\hline
\end{tabular}

Keterangan: $* *$ Berbeda sangat nyata

$\mathrm{CV}=2,24 \%$

B. Sifat Kimia Sosis Ayam yang meliputi kadar air, protein, lemak, abu dan karbohidrat. Kadar air sosis ayam yang dihasilkan berkisar antara $60,33 \%$ - 61,82\%. Sidik ragam kadar air disajikan pada Tabel 3, 
menunjukkan bahwa penambahan MOCAF sebagai bahan pengisi pada sosis ayam berpengaruh sangat nyata terhadap kadar air sosis ayam yang dihasilkan. Kadar protein sosis ayam yang dihasilkan berkisar antara 14,43\% -15,17\%.

Sidik ragam kadar air disajikan pada Tabel 3, menunjukkan bahwa penambahan MOCAF sebagai bahan pengisi pada sosis ayam berpengaruh tidak nyata terhadap kadar protein sosis ayam yang dihasilkan.

Tabel 3 Sidik ragam Kadar Air Sosis Ayam

\begin{tabular}{lccccc}
\hline $\begin{array}{c}\text { Sumber } \\
\text { Keragaman }\end{array}$ & db & $\begin{array}{c}\text { Jumlah } \\
\text { Kuadrat }\end{array}$ & $\begin{array}{c}\text { Kuadrat } \\
\text { Tengah }\end{array}$ & $\begin{array}{c}\mathbf{F} \\
\text { Hitung }\end{array}$ & $\begin{array}{c}\mathbf{F} \\
\text { Tabel } \\
\mathbf{5 \%} \\
\mathbf{1 \%}\end{array}$ \\
\hline Perlakuan & 4 & 4,7997 & 1,1999 & $\begin{array}{l}18,5172 \\
* *\end{array}$ & 3,48 \\
& & & & & 5,99 \\
Galat & 10 & 0,6480 & 0,0648 & & \\
Total & 14 & 5,4477 & & & \\
\hline
\end{tabular}

Keterangan : ** Berbeda sangat nyata $\mathrm{CV}=0,42 \%$

Kadar protein sosis ayam yang dihasilkan berkisar antara $14,43 \%-15,17 \%$. Sidik ragam kadar air disajikan pada Tabel 4 menunjukkan bahwa penambahan
MOCAF sebagai bahan pengisi pada sosis ayam berpengaruh tidak nyata terhadap kadar protein sosis ayam yang dihasilkan.

Tabel 4 Sidik ragam Kadar Protein

\begin{tabular}{lccccc}
\hline $\begin{array}{c}\text { Sumber } \\
\text { Keragaman }\end{array}$ & db & $\begin{array}{c}\text { Jumlah } \\
\text { Kuadrat }\end{array}$ & $\begin{array}{c}\text { Kuadrat } \\
\text { Tengah }\end{array}$ & $\begin{array}{c}\text { F } \\
\text { Hitung }\end{array}$ & $\begin{array}{c}\text { F } \\
\text { Tabel } \\
\mathbf{5 \%} \\
\mathbf{1 \%}\end{array}$ \\
\hline Perlakuan & 4 & 1,0895 & 0,2724 & $\begin{array}{l}2,0066 \\
\text { ns }\end{array}$ & 3,48 \\
Galat & 10 & 1,3575 & 0,1357 & & 5,99 \\
Total & 14 & 2,4470 & & & \\
\hline
\end{tabular}

Keterangan : ns Tidak Berbeda nyata $\mathrm{CV}=2,49 \%$

Kadar lemak sosis ayam yang dihasilkan berkisar antara $1,06 \%-1,20 \%$. Sidik ragam kadar air disajikan pada Tabel 5 menunjukkan bahwa penggunaan
MOCAF sebagai bahan pengisi pada sosis ayam berpengaruh tidak nyata terhadap kadar lemak sosis ayam yang dihasilkan.

Tabel 5 Sidik ragam Kadar Lemak

\begin{tabular}{lclllc}
\hline $\begin{array}{c}\text { Sumber } \\
\text { Keragaman }\end{array}$ & db & $\begin{array}{c}\text { Jumlah } \\
\text { Kuadrat }\end{array}$ & $\begin{array}{c}\text { Kuadrat } \\
\text { Tengah }\end{array}$ & $\begin{array}{c}\mathbf{F} \\
\text { Hitung }\end{array}$ & $\begin{array}{c}\mathbf{F} \\
\text { Tabel } \\
\mathbf{5 \%} \\
\mathbf{1 \%}\end{array}$ \\
\hline Perlakuan & 4 & 0,0383 & 0,0096 & 1,1169 & 3,48 \\
& & & & \\
Galat & 10 & 0,0858 & 0,0086 & & 5,99 \\
Total & 14 & 0,1241 & & & \\
\hline Keterangan $:$ ns & Tidak berbeda nyata & \multicolumn{2}{c}{$\mathrm{CV}=8,22 \%$}
\end{tabular}


Kadar abu sosis ayam yang dihasilkan berkisar antara 2,22\% 2,43\%, Sidik ragam kadar abu disajikan pada Tabel 6 menunjukkan bahwa penambahan

MOCAF

sebagai bahan pengisi pada sosis ayam berpengaruh tidak nyata terhadap kadar lemak sosis ayam yang dihasilkan.

\section{Tabel 6 Sidik Ragam kadar Abu}

\begin{tabular}{llllll}
\hline $\begin{array}{c}\text { Sumber } \\
\text { Keragaman }\end{array}$ & db & $\begin{array}{c}\text { Jumlah } \\
\text { Kuadrat }\end{array}$ & $\begin{array}{c}\text { Kuadrat } \\
\text { Tengah }\end{array}$ & $\begin{array}{c}\mathbf{F} \\
\text { Hitung }\end{array}$ & $\begin{array}{c}\mathbf{F} \\
\text { Tabel } \\
\mathbf{5 \%} \\
\mathbf{1 \%}\end{array}$ \\
\hline Perlakuan & 4 & 0,0961 & 0,0240 & 0,7899 & 3,48 \\
& & & & ns & 5,99 \\
Galat & 10 & 0,3041 & 0,0304 & & \\
Total & 14 & 0,4002 & & & \\
\hline
\end{tabular}

Keterangan : ns Tidak berbeda nyata $\quad \mathrm{CV}=7,38 \%$

$\begin{array}{lll}\text { Analisa kadar karbohidrat } & \text { antara 19,59\% sampai dengan } \\ \text { dilakukan dengan metode } & 21,74 \% \text {. Sidik ragam kadar } \\ \text { Carbohydrate by difference yaitu } & \text { karbohidrat sosis ayam disajikan } \\ \text { dengan menghitung kandungan } & \text { pada Tabel 7, menunjukkan bahwa } \\ \text { karbohidrat pada sosis ayam } & \text { penggunaan MOCAF sebagai bahan } \\ \text { berdasarkan hasil analisa kadar air, } & \text { pengisi berpengaruh sangat nyata } \\ \text { kadar abu, kadar protein dan kadar } & \text { terhadap kadar karbohidrat sosis } \\ \text { lemak. Kadar karbohidrat sosis } & \text { ayam yang dihasilkan. }\end{array}$

ayam yang dihasilkan berkisar

Tabel 7 Sidik Ragam kadar Karbohidrat

\begin{tabular}{llllll}
\hline $\begin{array}{c}\text { Sumber } \\
\text { Keragaman }\end{array}$ & db & $\begin{array}{c}\text { Jumlah } \\
\text { Kuadrat }\end{array}$ & $\begin{array}{c}\text { Kuadrat } \\
\text { Tengah }\end{array}$ & $\begin{array}{c}\mathbf{F} \\
\text { Hitung }\end{array}$ & $\begin{array}{c}\mathbf{F} \\
\text { Tabel } \\
\mathbf{5 \%} \\
\mathbf{1 \%}\end{array}$ \\
\hline Perlakuan & 4 & 9,6935 & 2,4234 & 10,7445 & 3,48 \\
& & & $* *$ & 5,99 \\
Galat & 10 & 2,2555 & 0,2255 & & \\
Total & 14 & 11,9490 & & & \\
\hline Keterangan : ** Berbeda sangat nyata & \multicolumn{2}{c}{$\mathrm{CV}=2,28 \%$}
\end{tabular}

Pada kesukaan Keseluruhan, semua parameter uji organoleptik sosis ayam meliputi warna, rasa, aroma, tekstur, dan kenampakan menjadi pertimbangan untuk menentukan suka dan tidak suka pada masing-masing perlakuan [4]. Histogram nilai uji kesukaan keseluruhan pada sosis ayam dapat dilihat pada Gambar 1

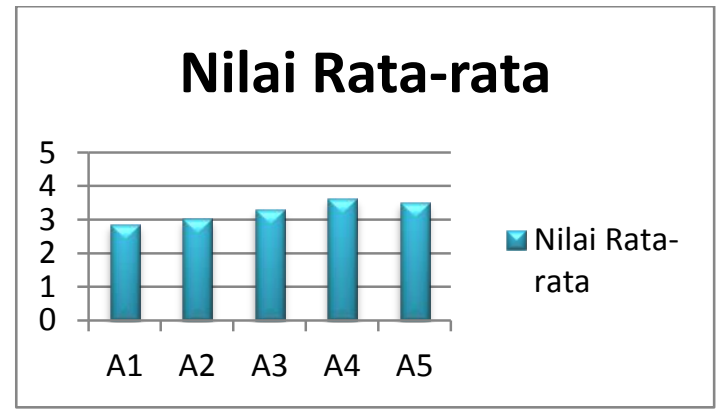

Perlakuan 
Gambar 1 Uji Kesukaan Keseluruhan Sosis ayam pada Berbagai Formulasi Penambahan MOCAF

\section{KESIMPULAN}

Penggunaan

(Modified Cassava Flour) sebagai bahan pengisi pada sosis ayam dapat mempengaruhi kadar air, kadar protein, dan kadar karbohidrat sosis ayam yang dihasilkan. Semakin banyak penambahan MOCAF dapat meningkatkan kadar air, kadar protein, serta menurunkan kadar karbohidrat pada sosis ayam. Semakin banyak penambahan MOCAF maka teksur sosis yang dihasilksn akan semakin lunak dan warna agak gelap, Berdasarkan uji kesukaan keseluruhan yang meliputi rasa, aroma, warna, tekstur, dan kenampakan diketahui bahwa sosis yang paling disukai adalah sampel dengan penambahan MOCAF $25 \%$ (A4), dengan kadar air sebesar $60,49 \%$, kadar protein $14,62 \%$, kadar lemak $1,10 \%$, kadar abu $2,42 \%$, dan kadar karbohidrat $21,37 \%$.

\section{REKOMENDASI [JIKA ADA]}

Rekomendasi ditujukan kepada perusahaan pembuat sosis atau lembaga yang mempunyai kewenangan untuk mengambil keputusan menyelesaikan masalahmasalah khususnya dalam bidang kesehatan makanan (BP POM).

\section{DAFTAR PUSTAKA}

Badan Standardisasi Nasional, 1995. SNI Untuk Daging Dan Produk Olahannya. Jakarta.

Rahman, A.M. 2007. Mempelajari Karakteristik Kimia Dan
Fisik Tepung Tapioka Dan

MOCAF (Modified Cassava

Flour) Sebagai Penyalut

Kacang Pada Produk

Kacang Salut, Skripsi,

Fakultas Teknologi

Pertanian Institut Pertanian

Bogor.

Saleh, S. 1996. Statistik Non

Parametrik. Yogyakarta: BPFE.

Suprapti, M.L., 2005. Pembuatan

Tepung Tapioka dan Pemanfaatannya. Cetakan I. Yogyakarta: Kanisius. 